\title{
Konceptuel imperialisme og engageret sympati i forskning om kvindelige sexsælgere
}

\section{Af JeAnett BJønness}

\begin{abstract}
Conceptual imperialism and engaged sympathy in research on female sex-sellers. This paper investigates academic knowledge production on sex-sellers' everyday life and strategies. Methodological discussions are first contextualized in public discourse on prostitution in Denmark characterized by a highly polarized debate often opposing 'the victim' to 'the autonomous individual' and second in the researcher's autobiography. The paper discusses how the researcher's own classed and gendered experiences affect the ethnographic research process. Does attempted identification with informants sometimes obscure valuable knowledge? Does it even sometimes lead to unintended kinds of 'othering' or 'epistemological imperialism'? The paper builds on data from long term fieldwork in a drop-in center for marginalized Danish women, life history interviews, and a critical reading of contemporary debates on prostitution in Denmark.
\end{abstract}

\section{KEYWORDS}

method, prostitution, class, gender, auto-ethnography, reflexivity/

metode, prostitution, klasse, køn, auto-etnografi, refleksivitet

Jeanett Bjønness er ph.d. i antropologi og adjunkt ved Center for Rusmiddelforskning, Aarhus Universitet. Hendes forskningsinteresser er bl.a. prostitution, stofbrug, køn og klasse. 


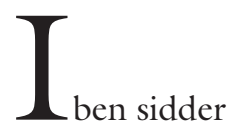

ved bordet med en halvrøget cigaret mellem sprukne, gule fingre. Ved bordet sidder også en pædagog, Hanne, og jeg, antropologen. Iben har svært ved at holde øjnene åbne og sidder og nikker med hovedet - hun 'kokser'. Med jævne mellemrum tænder hun en ny cigaret og beder om en varm kop kaffe, når den, der står med en flig af hendes lange pandehår i, er blevet kold. Hanne og jeg småsnakker og prøver at fă Iben med i samtalen. Hver gang cigaretten svinder ind, er vi parate til at gribe den, så den ikke brænder hendes fingre eller dugen. Vi er meget opmærksomme. Pludselig kaster Iben sit lange hår tilbage, maser skoddet ned i askebægeret og råber: "Har I nogen som helst idé om, hvor ubehageligt det er at sidde her og blive oversavlet af to skide pædagoger?" Hun går og smækker med døren (feltnoter 2001).

Ibens handlinger kan tolkes som en reaktion på at blive placeret $\mathrm{i}$ en bestemt kategori - 'den hjælpeløse bruger' - og dermed som afstandstagen til skabelse af en bestemt form for forskel. Hun gør modstand mod at blive behandlet som én, der er ude af stand til at tage vare på sig selv. Skeggs (1997:6) kalder det "a denial of the representations of their positioning". Eksemplet peger på 'hjælpens dilemma': Det, som personalet betragter som omsorg, opleves af Iben som ubehagelig kontrol. Konsekvensen bliver dels, at Iben går og afskærer sig fra eventuel hjælp, dels, at personalet konkluderer, at hun er 'utaknemlig' eller 'dårlig'.

Dagene på Stedet ${ }^{1}$ er fyldt med forhandlinger mellem brugere og personale og mellem brugere indbyrdes: En kiks mere, en time ekstra på Stedets sofa eller hvor lang skal en karantæne være? Udfaldet af disse små og store kampe er ikke givet på forhånd, men der er 'noget' ved dem, der gør, at de ofte falder ud på måder, som kvinderne oplever som nederlag. Dette 'no- get' og følelsen af ikke helt at føle sig 'hjemme' er et centralt omdrejningspunkt for kvinderne på Stedet, fordi det fører til handlinger, som for dem virker som rationelle og nødvendige i situationen, men som tit medfører yderligere marginalisering. Dette 'noget' i kampene er dog også et væsentligt aspekt af selve forskningsprocessen. Jeg vil i denne artikel prøve at forstå og belyse dette 'noget' med udgangspunkt i mine egne møder med kvinderne på Stedet, og ved at udforske, hvordan min egen baggrund, personlige erfaring og måde at 'gøre' køn og klasse på (Skeggs 1997; West \& Zimmerman 1987)2 påvirkede møderne med mine informanter, og hvordan situeret vidensproduktion (Haraway 1988) fandt sted i min forskning på et værested for marginaliserede kvindelige sex-sælgere.

I artiklens første del vil jeg belyse, hvordan den danske diskurs om prostitution under mit feltarbejde, med begreber som 'offer' og 'prostitution er vold mod kvinder' afspejles i de ansattes holdninger og indledningsvis påvirkede min forståelse af brugernes handlinger. Herunder vil jeg diskutere forskerens forpligtelser, når hun studerer 'ned', og videre, hvordan man kan skelne mellem 'bias' (skævhed) og engagement, når vi tager som udgangspunkt, at forskeren har sin egen selvfølgelige og 'kropsliggjorte' (Bourdieu 1995) forforståelse for feltet, når hun starter på feltarbejde. Artiklens anden del reflekterer over selve forskningsprocessen, med et særligt fokus på erindringsarbejde og på betydningen af min egen køns- og klassemæssige baggrund for de måder, jeg mødte, tolkede og repræsenterede mine informanter på. Artiklen slutter med en diskussion af, hvorvidt en bestemt form for 'othering' finder sted, når forskning gøres "i den gode sags tjeneste" (Jöhncke 2002; se også Margolin 1997). 


\section{FOKUS PÅ FORSKNINGSPROCESSEN}

På et både politiseret og moralsk omdiskuteret felt som prostitution kommer forskerens moralske og politiske værdier såvel som teoretiske antagelser i spil på specifikke måder (O'Connell Davidson \& Layder 1994:51; Bourdieu 1997; Hastrup 2010). Således kræver produktionen af troværdig, kvalitativ viden på dette felt en generel og øget refleksivitet, her forstået som en undersøgelse af "utænkelige tankekategorier, der udstikker grænserne for det tænkbare, og på forhånd bestemmer tankerne" (Bourdieu \& Waquant 1996:44), omkring, hvordan forskerens personlige erfaring påvirker forskningsprocessen (Bourdieu 2005).

Relationen mellem forsker og informanter kan forstås som et møde mellem to "sociale positioner"3 (Bourdieu 1995) i den forstand, at de respektive aktører bringer mere eller mindre forskellige kropsliggjorte erfaringer ind i mødet. Deres respektive baggrund, i denne artikel med særligt fokus på køn og klasse, ${ }^{4}$ eksisterer som referencerammer, som aktørerne bringer med på forskellige og ofte ikke-bevidste måder (Bourdieu 1995; Faber 2008; Skeggs 2004). Dette betyder, at interviews eller andre mellemmenneskelige situationer og hændelser fortolkes og erfares (kropsliggøres) forskelligt af parterne i relationen (se også Haraway 1988). Køn og klasse er således relationelle begreber, der 'gøres' i bestemte sociale rum, og hvor forskellige former for kapital og erfaring kommer i spil. I denne artikel betragtes det empiriske udgangspunkt Stedet, analytisk som et 'felt' i Bourdieus (1995) forstand; et socialt rum konstitueret af konflikter og daglige kampe, hvor forskellige sociale positioner mødes, og hvor nogle positioner er mere determinerende for strukturen (Bourdieu 1996: 223), og har større muligheder for at opnå social eksistens (Bourdieu 1997:54), end andre. Et fokus på 'klasset' og 'kønnet' baggrund indikerer således, at forskerens erfaring er mere eller mindre nær hendes informanters og ydermere, at den ligger tættere på visse informanters erfaringer frem for andres i dette felt (O'Connell Davidson \& Layder 1994).

Artiklen diskuterer de måder, hvorpå min egen erfaring kom i spil i specifikke empiriske situationer, og søger således at udøve det Bourdieu kalder 'epistemologisk påpasselighed' (2005:142) eller 'indlevet objektivering' (1996:60).5 For mit projekt er dette vasentligt, ikke mindst fordi nogle af mine informanter blev 'allierede' og venner. Vi var i én forstand ens, fordi vi var alle kvinder, men var også forskellige, da vi kom som henholdsvis ansat/forsker og klient/ bruger fra generelt ganske forskellige sociale baggrunde. I vore møder representerede vi således både ens og forskellige sociale positioner, hvilket påvirkede vore respektive forestillinger om, hvad vi var fælles om. Det betød, at jeg, særlig i begyndelsen, trak nogle slutninger ud fra egen erfaring, som viste sig at se helt anderledes ud fra informanternes perspektiv. Der hvor jeg så problemer, så de agens, og vice versa. Eftersom kønnede og klassede erfaringer naturligvis er dynamiske og i kontinuerlig forandring, blev den 'omsorgsfulde distance', som eksemplet ovenfor illustrerer, senere i forskningsprocessen til et langt mere engageret, men også mere modsætningsfyldt forhold. Jeg havde i en periode svært ved at håndtere både informanternes og egen afmagt, vrede og sorg - og følte til tider tilmed afsky over for dem, jeg senere skulle skrive om. I forvirringen og frustrationen blev Karin Widerbergs (1994) studie af sammenhænge mellem køn og kundskab, hvor hun introducerer erindringsarbejde som videnskabelig metode, min anledning til at tage time out på Stedet og skrive min egen livshistorie. Dette erindringsarbejde viste sig at åbne op for nye epistemologiske dimensioner af forskningsprocessen. 
I DEN GODE SAGS TJENESTE

- FORURENING ELLER ENGAGEMENT PÅ PROSTITUTIONSFELTET

How can we claim to engage in the scientific investigations of presuppositions if we do not work to gain knowledge of our own presuppositions? (Bourdieu 1999: 608)

I den tid, jeg var på feltarbejde på Stedet (2001-2005), udgjorde gadeprostitution cirka 10 procent af det danske prostitutionsmarked (NBSS 2014). En stor og disproportional del af den offentlige debat handlede dog om stofbrugende kvinder, som solgte seksuelle ydelser på gaden, og senere om handlede kvinder: 'trafficking-ofre'. Generelt var prostitution et ekstremt politiseret tema i den offentlige debat. En særlig version af radikalfeminismen praktiserede en 'konceptuel imperialisme' (Stanley \& Wise 1993), og begreber som 'offer' og 'prostitution er vold mod kvinder' optog medier og hjælpeorganisationer mere end emiske 6 begreber som handling, kontrol og nødvendighed (Bjønness 2008, 2013; Spanger 2011; Skilbrei \& Holmstrøm 2013). Selv om eksisterende litteratur beskrev danske sex-sælgere som relativt uafhængige, blev 'den prostituerede' i medierne ofte beskrevet som undertrykt af voldelige alfonser, bagmænd og kunder (Rasmussen 2007; Helth 2011). Det er veldokumenteret, hvordan dette 'undertrykkelsesparadigme', i hvilket prostitution blev betragtet som iboende skadeligt (Weitzer 2012: 16), trivedes i danske medier i denne periode (Sørensen 2004, Bjønness 2008), og hvordan billedet af 'den prostituerede', som et sårbart offer for mænds vold, dominerede offentlige debatter (KFUK 2004; Bjønness 2012; Skilbrei \& Holmstrøm 2013). Forsøg på at fremføre andre perspektiver, f.eks. at se på sex-salg som en aktiv beslutning eller at fokusere på juridiske rettigheder, var svære at fă gennemslag for og blev nogle gange latterliggjort (Bjønness 2011, 2013; Spanger 2011 ; Rasmussen 2007; Bømler 2008).
Den amerikanske sociolog Ronald Weitzer (2005) hævder, at megen eksisterende litteratur om prostitution har suspenderet etablerede retningslinjer for videnskabeligt arbejde, og at forskningen har favoriseret særlige politiske dagsordener. Weitzer beskriver denne forskning som 'inficeret', og argumenterer for mere ideologisk neutral (objektiv) forskning (ibid: 946). I modsætning til Weitzers efterspørgsel efter objektivitet efterlyser flere antropologer en mere engageret forskning (Groes-Green 2002; Ahmed \& Shore 1995). Jöhncke (2002: 29) argumenterer f.eks. for, at antropologers hovedforpligtelse er at formidle 'the actor's point of view', tage aktørers kritik af magtulighed alvorligt samt at inkludere i vores analyser aspekter, som umiddelbart kan virke irrelevante. Som Young (1997: 346) skriver:

The idea of a symmetry in our relation to our informants obscures the difference and particularity of the other position. It is also ontologically impossible for people in one social position to adopt the perspective of those in the social positions with which they are related in social structures and interaction.

Det er således ikke muligt at have et 'gudeblik' (Haraway 1988); transparent, situeret viden, hvor vi reflekterer over eget engagement og egne forforståelser, er det nærmeste, vi kommer på objektivitet.

\section{RELATIONEN MELLEM DISKURS OG FORSKNINGSPRAKSIS}

Den ovenfor beskrevne offentlige debat, som også afspejlede sig i de måder, hvorpå Stedets ansatte betragtede sig selv som kvindernes beskyttere, advokater og 'stemme' (KFUK 2004), spillede en central rolle for mine første møder med personale og brugere på Stedet. Organisationen bag centret havde en fremtrxdende stemme i den offentlige debat om prostitution og anbefale- 
de en kriminalisering af købere af seksuelle ydelser gennem en offer-overgriber retorik:

Det ekstreme salg er og bliver prostitution det at sælge adgang til sin krop via prostitution og pornografi - vil altid være det ekstreme salg, og en situation der ikke kan sammenlignes med noget andet (KFUK 2004).

Ydermere var det tydeligt på Stedets personalemøder og i omtale af brugere i den daglige samtale mellem kollegaer, at personalet, som alle var kvinder, associerede prostitution med sårbarhed og undertrykkelse. Min feltdagbog afslører, hvordan min egen tænkning om prostitution i projektets første fase i store træk var overensstemmende med det dominerende offer-billede. I mine tidlige feltnoter fremgår, at jeg forventede, at mine informanter ville fortælle tåredryppende historier om deres første kunde, fordi jeg antog, at den erfaring måtte have været meget grænseoverskridende for dem. Dette ses f.eks. i denne ureflekterede narrativ om mandlige overgribere og kvinder som ofre fra min feltdagbog: "Lille Vera. Hvorfor fanden behøver hun at være i denne situation? Og hvad slags mænd er det, som køber hendes lille krop nede i gaden?" (feltnote, 2002).

De fleste talte dog om deres første kunde på en distanceret måde og sagde f.eks.: "han var beskidt, men han betalte godt" eller "han var den første person overhovedet, som behandlede mig med respekt". Dette overraskede mig og fik mig også nogle gange til at føle decideret kvalme. Når kvinderne på den anden side grædende og sørgende fortalte om, hvordan de havde følt sig svigtet og forladt af deres egne mødre og kærester, blev jeg vred og følte behov for at spørge: "Hvorfor finder du dig i det?" Det fremgår således af feltdagbogen, at nogle af de aspekter af deres liv, som jeg, med min forventning om at møde ofre, troede var problematiske, af dem blev opfattet som nødvendige, uproblematiske eller endda gav en følelse af magt. Hvorimod aspekter
- som jeg og det sociale system i øvrigt troede ville forbedre deres livssituation, som opbygning af relationer til venner, familie og det sociale system - i deres narrativer blev fremstillet som problematiske og ødelæggende.

I begyndelsen var jeg således på linje med personalets vurderinger, når de betragtede sex-salget og volden som kvindernes hovedproblemer:" "Hvordan kan de få sig selv til at sælge det, som vi giver af kærlighed?" (Anna, personale, 2001). Jeg tog det for givet, at en positiv forandring for dem ville være at undgå at sælge seksuelle ydelser, og at jeg kunne bidrage til at give dem et bedre liv og en offentlig stemme ved at engagere mig i det sociale arbejde på værestedet (se også: Mazzei 2009). Det følgende udskrift fra et tidligt interview med Sarah, i hvilket hun inden har fortalt om en barndom fuld af overgreb og savn, demonstrerer min søgen efter kausalitetsrelationer mellem hendes baggrund, volden, og det, at hun nu sælger seksuelle ydelser - en kausalitet, som Sarah hverken genkender eller accepterer:

Sarah: Det forstår jeg ikke, for mange vælger det (sex-salg) da selv, hvordan kan det så være vold $(\ldots)$

JB: Men Stedets leder siger f.eks. at ved at legalisere prostitution, blåstempler vi som samfund volden.

Sarah: Det lyder lidt søgt for mig, for sådan har det ikke været for mit vedkommende... jeg har selv valgt det med fuldt overlæg, og jeg føler ikke, at jeg på noget tidspunkt har været socialt belastet!

JB: Nej, men du har jo oplevet... altså... udefra kan det se ud, som om du har oplevet nogle ting i din barndom og ungdom, som mange andre ikke har, du har f.eks. mistet din mor tidligt, været i pleje, og oplevet...

Sarah (afbryder): Ja, men sådan vil det jo være for alle mennesker, uanset om man er prostitueret, eller hvad man er. Jeg synes ikke nødvendigvis, det gør mig til offer på nogen måde (...) for nogle af de ting der, de har jo gjort, at jeg er den, jeg er, ikke. 
Sarah modsætter sig mine forsøg på kategorisering og insisterer på at være et ikke-offer - en aktør.

Men eftersom jeg på det tidspunkt fremdeles ganske enøjet så efter ofre og sårbarhed, tenderede jeg mod at drage den samme konklusion som mine omgivelser og kollegaer: Sarah forstod ikke helt sin egen situation, og hendes narrativ var et forsøg på at legitimere egne valg.

Langsomt begyndte dog tvivl, paradokser og dilemmaer at snige sig ind. I det følgende vil jeg fokusere på to væsentlige temaer i min forskningsproces som producerede ny indsigt: rolleskift og autobiografi.

\section{NyE ROLLER OG FØLELSESMÆSSIGE RUTSJETURE}

En vigtig fase begyndte, da jeg startede med at bruge min bil i hverdagen på Stedet. At jeg kunne køre brugerne ud af institutionen og dermed være med i deres liv udenfor på en anden måde end før, gav adgang til nye sfærer i deres liv. Biografbesøg, sygebesøg, familiebesøg, ferier, begravelser og ikke mindst det at være med til at besøge deres børn i familiepleje eller institution gav mig værdifuld indsigt $i$ hverdagslivets kompleksitet. På en fire dages fisketur med Vera, der af personalet var kategoriseret som en af de mest 'svære' brugere, fik jeg mulighed for at opdage nogle af hendes kompetencer: hendes stolthed, da hun sad ved roret i fiskerbåden, hendes erfarne måde at håndtere fiskenettene og fiskene på, og den middag hun lavede til os af den selvfangede fisk. At se hende sidde roligt på sommerhusets terrasse og se ud over havet, gjorde indtryk på mig; her kunne hun udleve sider af sig selv, som var umuliggjort i den institutionelle sammenhæng.

Nye roller og nye relationer uden for institutionen gav mig som forsker en øget bevidsthed om og opmærksomhed på kvindernes kompetencer og refleksioner i modsætning til det offer-billede, som var domi- nerende både $\mathrm{i}$ institutionen og $\mathrm{i}$ den offentlige debat.

Jo tættere jeg kom på mine informanter, des oftere fik jeg adgang til deres forskellige, og for mig ofte overraskende, narrativer både om social baggrund og om deres nuværende livssituation. F.eks. begyndte jeg at lægge mærke til kundehistorier, som handlede om sjove episoder, om hvordan 'dumme' kunder kunne snydes, og om sex-salget som 'nemme penge', mens de problematiske aspekter af sex-salget var mindre fremtrædende. At kvinderne knyttede sex-salget til frihed og til en oplevelse af, at de var i kontrol, blev endnu tydeligere, da jeg begyndte at interviewe dem:

Jeg ville være min egen herre på den måde der. Jeg følte mig fri, og det var måske også det, som holdt mig oppe, altså. Så jeg sagde nej til de fleste, og mange syntes, at jeg var en kold skid. Men det var jo mig selv, der skulle overleve, ikke, så det gjorde jeg faktisk rimelig godt. (Sarah, interview, 2002)

Jeg har været sammen med dem, og så har jeg tømt deres pung... ja... fordi jeg syntes, de var for nærige... at de fortjente det.(Line, interview, 2003)

Prostitutionen som problem fyldte ikke mine informanters narrativer, men svigt, økonomi, ensomhed, hjemløshed, relationen til deres børn og øvrige familie, afhængighed, psykiatriske sygdomme, fysiske sygdomme, vold og stigmatisering gjorde. Ydermere stod det efterhånden også klarere for mig, at de oplevede sex-salg som et nødvendigt og aktivt valg mellem tilgængelige alternativer, f.eks. kriminalitet, snarere end noget, som "bliver gjort mod en." Min temmelig endimensionelle problemdefinition blev således udfordret, og rationalerne bagved deres handlinger gav langsomt mere mening for mig.

Det, at jeg trådte ud af ansatte-rollen og dermed i mindre grad var underlagt institutionens regler, betød imidlertid også, at 
nogle af brugerne begyndte at betragte mig som deres nærmeste kontaktperson og som 'deres'. Flere kollegaer gav udtryk for frustration, da de følte, at jeg kunne tilbyde kvinderne en fleksibilitet og intimitet, som de, underlagt institutionens regler og retningslinjer, ikke kunne. En 'kamp om brugerne' blev synlig for mig, og Stedet begyndte i stigende grad at fremstå som et socialt rum (Bourdieu 1995) bestående af konflikter og daglige kampe. Specielt trådte personalets kategorisering af de 'nemme' og de 'besværlige' brugere tydeligere frem i mine feltnoter. Endvidere viste min hverdag med brugerne uden for Stedet, at lige så vel som 'vi' havde klare forestillinger om 'dem', havde 'de' klare forestillinger om 'os'. Udsagn som “skide pædagoger”, "hun er en af dem, som aldrig ville blive $10 \mathrm{mi}$ nutter ekstra", "hun er da korrupt" og lignende, begyndte at fylde feltdagbogssiderne. Brugerne opererede tydeligvis med personale, som 'kunne bruges' og personale, som ikke kunne, hvor et af kriterierne for at være 'brugbar' var at være villig til at omgå regelsystemet for at hjælpe en bruger.

Et eksempel var da Line, på en køretur med mig, ringede til en af de ansatte og fortalte, at hun ville komme for sent til deres aftale. Den ansatte sagde, at hun ikke kunne vente, og at de blev nødt til at lave en anden aftale, hvilket fik Line til at udbryde:

Den so kunne da aldrig drømme om at blive en time ekstra for en brugers skyld. Det er forskellen på gode og dårlige medarbejdere, om de er villige til at være lidt fleksible eller ej! (...) Du ville da til enhver tid vente nogle minutter ekstra, hvis jeg ringede og var på røven, Jeanett!? (Feltnote 2004)

Mine nye tilskrevne roller som 'god' eller 'ikke-ansat' producerede således nye perspektiver, og mine egne forhåndskategorier blev udfordret af, at jeg blev inddraget i 'deres' kategorisering af 'os' og til dels inddraget i deres 'vi'. Det blev tydeligt, at in- stitutionen kun tillod bestemte narrativer og roller, så som 'ofret' og 'hjælperen', mens andre og mere komplekse roller og relationer var tilgængelige uden for institutionen.

En mere kompleks forståelse for feltet er jo som sådan ikke noget overraskende resultat af et langvarigt forskningsprojekt. Mere overraskende var den følelsesmæssige rutsjetur, som fulgte med mine nye tolkninger af kvindernes handlinger og narrativer. Jo nærmere jeg kom på kvinderne og deres oplevede nødvendighed, desto flere konflikter oplevede jeg i forhold til mine egne forskellige og ofte uforenlige roller oscillerende mellem personalets og brugernes perspektiv. Stadigt oftere føltes dét at skulle håndhæve Stedets regler som et overgreb på brugerne, og jeg begyndte at overveje, hvorvidt meget af det, som blev taget for givet $\mathrm{i}$ institutionen (og på det tidspunkt, også delvist af mig selv), var ligeså meget en del af problemet som af løsningen for brugerne (se også Herzfeld 1997; Gubrium \& Järvinen 2014).

Jeg fandt på dette tidspunkt tiltagende mig selv på 'brugerens side' (Becker 1967) i konflikter og diskussioner på Stedet, og mere specifikt optrådte jeg i stigende grad som advokat for en bestemt gruppe af Stedets brugere, nemlig dem, som af personalet ofte blev beskrevet som "utaknemlige", eller som "usamarbejdsvillige". Line, som ofte blev beskrevet af personalet som "vanskelig" og "langt ude", reflekterede i flere interviews over, hvordan det på Stedet var nødvendigt for hende at opføre sig på bestemte måder for at bevare sin selvrespekt. "Jeg har altid været vild", sagde hun med et grin, for at forklare hvorfor hun fik så mange karantæner. Sarah, derimod, virkede kompetent både $\mathrm{i}$ interviews og $\mathrm{i}$ den institutionelle kontekst, og blev tit beskrevet som "fornuftig" og "ansvarsfuld" af personalet. En anden af mine nøgleinformanter, Maria, skrev til mig i et brev; "jeg mestrer at være tam, men ikke tro på det, for det er bare en facade". Ved at bruge de emiske 
kategorier 'tam' og 'vild' begyndte jeg at tænke på mine informanter som nogle, der benyttede enten 'vilde' taktikker, hvor de vedholdende modsatte sig de institutionelle kategorier eller 'tamme' taktikker, hvor de tilpassede sig institutionelle normer og retningslinjer for at modtage omsorg eller konkrete goder. Det stod hurtigt klart, at min sympati var hos de kvinder, som benyttede de 'vilde' taktikker. Allermest lå min sympati hos kvinder som Andrea, der vekslede mellem 'vilde' og 'tamme' taktikker og hele tiden reflekterende over, hvad som bedst kunne betale sig i den specifikke situation. De ansatte kategoriserede hende som "tung”, "skrupelløs" og som “en, der ikke havde selvindsigt". I min feltdagbog (2004) beskrev jeg hende derimod som et menneske med "stor integritet" og den "mangel på ydmyghed", jeg så i hendes måde at gebærde sig på, som "stærk" og "sund". Hendes narrativ, hvor læreres, terapeuters og socialarbejderes manglende anerkendelse og hjælp var afsæt for teorier om hvordan "normale relationer og et godt liv" var uopnåeligt for hende, rørte og fascinerede mig.

Kontrasterne mellem, hvordan kvinderne præsenterede sig selv i interviews, og hvordan jeg nogle gange så dem i deres hverdag, var imidlertid følelsesmæssigt svære at håndtere. De kvinder, som jeg sympatiserede så stærkt med, dem med de 'vilde' taktiker og genkendelige narrativer, handlede tit på måder, som jeg opfattede som irrationelle og kaotiske (se også: Loseke 2001). Desuden opstod konflikter og vrede, når intimiteten $\mathrm{i}$ interviews og samtaler var uforenelige med det, at jeg skulle give kvinderne karantæne eller andre sanktioner, i rollen som ansat. Som Vera, frustreret og forvirret, råbte det, efter at have kastet en cykel efter mig: "Jeg troede, du forstod!" Stadig oftere følte jeg tristhed og forvirring i min relation med kvinderne. Jeg græd ofte, og jeg følte mig så drænet for energi, at jeg til sidst nærmest ikke kunne slæbe mig til Stedet. Efter at have foretaget nogle dybt for- virrende og frustrerede livshistorieinterviews, besluttede jeg at tage en pause fra Stedet for at skrive min egen livshistorie.

\section{ERINDRINGSARBEJDE SOM FORSKNINGSSTRATEGI}

Det at skrive min egen livshistorie tillod mig at 'opdage' tidligere 'usynlige' kontekster både for min interesse i prostitutionsfeltet og min forvirring i forskningsprocessen. Mine erindringer blev en historie om tidspunkter i livet, hvor mit køn og min arbejderklassebaggrund ${ }^{8}$ kom i spil (se f.eks. Seljestad 2005), og hvor jeg selv havde erfaret stempling og stigma. De følgende fire nedslag i min historie bidrager i det følgende til en argumentation om, at auto-etnografi kan hjælpe med at forstå verden gennem at tildele egen erfaring mere opmærksomhed. Teknikken kan forbinde det personlige til det kulturelle, det sociale og det politiske (Ellis 2004, andre referencer til auto-etnografien: Baarts 2010; Gullestad 1989; Ellis \& Bochner 2000; Heider 1997; Mahoney 2007; Sanjek 1990). Dermed udgør den et værdifuldt metodisk redskab når den vel og mærke ikke henfalder til narcisisme (Bourdieu 2005: 143).9

1) På min barndoms $\varnothing$ boede en familie med en masse børn. En af de store piger i familien, Renate, gik i min klasse. Hun var ligesom altid lidt fremme i skoene, gik i anderledes tøj og legede med drengene. Så en dag forsvandt nogle penge til en fødselsdagsfest. "Det var nok Renate..." Efter det blev hun én, man ikke måtte lege med. Familien flyttede væk, da hun blev gravid. 'De respektable' blev bekræftet i dommen: Renate og hendes familie var ikke som 'dem'. Jeg husker min egen ambivalens og en forvirret solidaritet med Renate, som jeg aldrig turde udtrykke.

2) I teenageårene gik mine veninder og jeg meget i byen. På et tidspunkt gik der rygter om, at vi var 'billige' - at vi gik i seng med de drenge, vi var til fest med. Jeg husker den lammende tanke, at jeg ikke 
kunne kontrollere det offentlige billede af mig som person, men også min undren over, at mine veninder, som, i modsætning til mig, kom fra middelklassefamilier, ikke delte min bekymring.

3) Tidligt i 80'erne begyndte jeg fuld af indignation over social uretfærdighed at læse kriminologi på universitetet. Så rejste jeg ud i verden, personligt vaklende, men skråsikker på, hvad der var ret og forkert. Mit bidrag til opbygningen af Nicaragua efter den sandinistiske revolution var nok begrænset, og jeg opdagede, at vores solidaritetsarbejde var fyldt med dilemmaer. Jeg så ydermere køn konstrueret og levet på radikalt anderledes måder end derhjemme.

4) I 1997 afleverede jeg specialet 'Modernitetens frie slaver' om de dilemmaer, unge skandinaviske kvinder kan opleve i krydsningsfeltet mellem individualisme og relationisme. Som mor til to små børn og studerende, oplevede jeg, at den frihed og lighed, jeg havde taget for givet, og som bl.a. gjorde, at jeg følte mig så anderledes end kvinderne i den nicaraguanske landsby, blev udfordret.

Disse nedslagspunkter i min egen livshistorie syntes umiddelbart at danne en rød tråd, som var forbundet med baggrunden for min interesse for grænserne mellem det normale og det afvigende og senere prostitution; den 'respektable' og den 'forkerte' kvinde (Skeggs 1997). Tråden 'opdagede' marginalisering, først som personlig erfaring og dernæst som forskningsfelt, og illustrerer dermed, at biografien er en illusion (Bourdieu 1997), der viser en tendens til at forme livets kaos til en konstrueret retlinjet logik (Järvinen 2000). Konstruktionen er dog langt fra tilfældig, men peger netop på den konkrete empiriske kontekst, den er formet i, som en helt central del både af selve fortællingen og tolkningen af den. I dette tilfælde var denne kontekst min forvirring omkring grænserne mellem 'dem' og 'mig'. Mine problemer med at håndtere de følelsesmæssige påvirkninger af kvindernes fortællinger om deres liv og kampe, og om en grundlæggende følelse af at føle sig udenfor og anderledes, var selve afsættet for mit erindringsarbejde. De konkrete nedslag ovenfor viser, at min sociale position både var tæt på og langt fra deres, men jo også at jeg i høj grad skrev min egen erfaring $i$ lyset af deres. Når deres narrativers smerte ramte mig 'i maven', var det måske, fordi deres smerte $\mathrm{i}$ mig aktiverede et personligt spørgsmål: Kunne det have været mig? $\mathrm{Og}$ ydermere: Hvorfor havde jeg været så bange for at virke 'billig'? Var det tilfældigt, at jeg ikke blev taget af politiet, da jeg kørte beruset i en uregistreret bil, at jeg ikke blev voldtaget, da jeg vaklede hjem fra byen, at jeg ikke blev forelsket i en mand, der var voldelig, eller at jeg ikke røg hash og spiste piller som så mange andre i min omgangskreds? Hvad adskilte 'mig' fra 'dem'? Hvorfor ville jeg 'redde verden'? Hvad er udslagsgivende for, om marginalitet bliver til en 'karriere' (Becker 1963)? I det lys gav mit fysiske ubehag, kvalme, svimmelhed og uro pludselig mening.

At jeg ikke havde reflekteret over egen historie på denne måde, før jeg startede på feltarbejdet, og alligevel anså emnet for min ph.d. som oplagt, viser således, i følge Bourdieus logik, at ens livshistorie også hænger sammen på andre måder end det, man på et givet tidspunkt er klar over:

It is because subjects do not, strictly speaking, know what they are doing that what they do has more meaning than they know. The habitus is the universalizing mediation which causes an individual agent's practices, without either explicit reason or signifying intent, to be none the less 'sensible' and 'reasonable'. That part of practices which remains obscure in the eyes of their own producers is the aspect by which they are objectively adjusted to other practices and to the structures of which the principle of their production is itself a product (Bourdieu 1977:79).

Retrospektivt er det imidlertid oplagt, at 'den prostituerede' interesserede mig, fordi 
jeg - både med hensyn til klasse og køn så hende som den mest stigmatiserede figur. Dér var magten sat på spidsen. Dér var en marginaliseret gruppe, der behøvede en stemme. Dér var mit projekt og faglige fokus! At projektet også handlede om mere personlige spørgsmål, som oplevet anderledeshed og grænser for agens, blev dog først tydeligt gennem erindringsarbejdet.

\section{FASCINATIONEN AF 'VILDE' TAKTIKKER}

Det ovenstående viser, at netop refleksion over individuel erfaring (både forskerens og informanternes) gør analyser af sammenhænge mellem aktørers praksis og struktur muligt. Således illustreres habitus som et dobbelt spor: individuelle beslutninger er indvævede i en social empirisk virkelighed, som for en stor del ikke er tilgængelig for refleksion (Bourdieu 1977). Det blev klart for mig, at fokuspunkterne i min livshistorie netop var en mere eller mindre ikke-bevidst legitimering af egne dispositioner, og hvordan ydre rammer i samspil med egen sociale position og agens konstituerer både muligheder og begrænsninger. Mine egne overvejelser over egen 'klasserejse' (Ambjörnsson 1996; Sejlestad 2005), relationen mellem egen baggrund og valg af forskningsfelt, såvel som 'opdagelsen' af i hvilken grad min egen narrativ var en konstruktion, gav mig nye redskaber i min bestræbelse på at analysere, hvordan kvinderne på Stedet skabte mening og sammenhæng i bestemte empiriske sammenhænge. Disse redskaber inkluderede at tolke livshistorier, også min egen, som kontekst-specifikke narrativer, som peger på strukturer af køn og klasse, som kun er epistemologisk tilgængelige gennem refleksioner omkring deres 'skabelse' (Wagner 1981). Uden situerede refleksioner over 'livsbaner' (Bourdieu 1995) forbliver strukturer og mekanismer uigennemsigtige.

Erkendelsen af, at min egen livshistorie var konstrueret på bagrund af og tilpasset til en bestemt situation og kontekst, gjorde det muligt også at tolke mine informanters narrativer som situationelle (Haraway 1988) og ikke som mere eller mindre 'sande' eller troværdige, som jeg havde haft en tendens til at gøre inden. Samtidigt gav de en kontekst for at forstå, hvorfor bestemte brugeres narrativer appellerede så stærkt til mig. Metoden åbnede for en anerkendelse af, at de centrale 'plots' (Mattingly 1998) i en livshistorie kan tolkes som en mere eller mindre tilsigtet selv-iscenesættelse. Det blev klart for mig, hvordan mine valg om at privilegere og forfølge bestemte typer af narrativer fremfor andre ikke blot konstituerede et etisk og metodisk tema, men også spillede en rolle rent epistemologisk.

Ydermere åbnede refleksionen over egen sociale position som kontekst for projektet, og hvordan netop erindringsarbejde kan nuancere tilsyneladende deskriptive og selvindlysende kategorier (Syltevik 1998), for et syn på livshistorier, også min egen, som 'diskursive effekter', der peger på strukturer, som kun er tilgængelige gennem refleksion over deres betydning:

What we must always remember is that the autobiographical mode involved a re-telling of 'experience', not of a pre-given reality; rather our life-stories are the discursive effects of processes that we call upon to construct and reconstruct what we call 'reality' (Brah citeret i O’Neill 2001: 54).

Uden den enkelte historie forbliver strukturerne og vigtige mekanismer med betydning for praksis usynlige og ureflekterede (doxa). Den enkelte historie kan betragtes som en refleksion over tilblivelsen af analytiske begreber og i sidste ende over resultaterne af forskningen. Det handler altså om at gøre forskningens præmisser så tydelige som muligt både for forsker og læser.

Når de i mine øjne mest reflekterede informanter var dem, der interesserede mig mest og også var dem, jeg kom tættest på, tror jeg, at det var på grund af de værdighedskampe, jeg tolkede ind i deres handlin- 
ger. Omvendt gjorde denne interesse måske, at netop kvinderne med 'vilde' taktikker mærkede min anerkendelse og følte sig godt tilpas i relationen.

Uanset kastede processen med at skrive min egen livshistorie lys over en ikke-reflekteret eller i hvert tilfælde ikke-tilstrækkeligtreflekteret identifikation i min relation til kvinderne i min undersøgelse, og på et personlig plan kastede denne erkendelse lys over den udprægede grad af identifikation og berørthed, jeg oplevede, da mine informanter fortalte deres historie. Det begyndte at gå op for mig, at min oplevelse af, at det var tungt og ofte sørgeligt at være sammen med kvinderne, havde at gøre med min egen emotionelle erindring og ambivalens og mine egne oplevelser af at føle mig anderledes som kvinde fra en arbejderklassebaggrund.

Det, jeg indtil da havde oplevet som mine informanters 'sårbarhed', 'manglende forståelse for egen situation' eller 'irrationel adfærd', kunne jeg nu forstå som agens, modstand og aspekter af deres kamp for anerkendelse. Min analyse af et interview med Andrea (2004) illustrerer dette, hun sagde blandt andet:

Jeg har været sammen med hele verden, fra jeg var 15, jeg har bare ikke fået penge for det... Jeg har jo brugt det der udtryk, at jeg byttede sex for kærlighed - men det gjorde jeg jo ikke, jeg blev jo behandlet som en luder... det bliver man selvfølgelig ikke luder af, men jeg vil faktisk vove den påstand, at det er mere ødelæggende end at få noget for det... Fordi hvis du får noget for det, så kan du i det mindste grine af dem bagefter og tænke: "ha, ha, hvor er de dumme, at de vil betale mig for det", ved du hvad, sådan tænker jeg, Jeanett: 'Ha, ha, at de vil betale mig for det, jeg har gjort gratis i så mange år.'

Nu kunne jeg analysere dette citat (også) som en historie om have kontrol - hun snyder kunden, ikke omvendt, og hun repræsenterer på ingen måde sig selv som 'prosti- tueret' eller 'sexarbejder' i identitetsmæssig forstand, men italesætter det at sælge seksuelle ydelser som én handling, blandt andre. Da jeg begyndte at forstå, hvordan Andrea og andre med hende evaluerede og kontekstualiserede deres handlinger som taktikker til at opnå kontrol (se også Skilbrei 2003), begyndte jeg at stille nye typer af spørgsmål til rationalet bag sexsalget og hvilken betydning det havde i deres tilværelse og $\mathrm{i}$ forhold til deres beslutninger mere generelt. Den vigtigste indsigt var dog, at et socialt felt som et analytisk rum ikke kan bestå af 'ofre' og 'hjælpere', men snarere består af individer, inklusive mig selv som forsker, som agerer i forskellige roller ud fra forskellige sociale positioner (Bourdieu 1995), og kxmper for at opnå symbolsk kapital (ibid.) med forskellige dispositioner og interesser i specifikke sociale situationer.

\section{KONCEPTUEL IMPERIALISME ELLER ENGAGERET SYMPATI?}

Når jeg har argumenteret for, at kvalitative forskere skal udøve 'epistemologisk påpasselighed' (Bourdieu 2005:142) ved, i så vid udstrækning som muligt, at bruge analytiske redskaber til at objektivere deres egen vidensproduktion og gøre den gennemsigtig, er det også på sin plads at påpege, at også denne objektivering er en konstruktion.

Jeg erfarede nemlig også, at mit forsøg på gennemsigtighed ikke kunne fjerne min forvirring omkring håndteringen af den store diversitet i mine informanters narrativer og strategier, og 'opdagelsen' af min særlige forkærlighed for de 'vilde' taktikker. Mine sympatier, og hvordan jeg engagerede mig, havde åbenbare konsekvenser for, hvad jeg i forskningsprocessen kunne 'se', og hvad der på forskellige tidspunkter og måder var 'usynligt' for mig. Men det havde også konsekvenser for, hvordan jeg tolkede mine data og for, hvad jeg valgte at repræsentere (se også Phoenix 1999: 11). 
I den sidste del af denne artikel vil jeg derfor diskutere nogle mulige epistemologiske implikationer af, hvordan min egen doxa, som 'klasset' og 'kønnet' forsker, påvirkede mine valg, refleksioner og søgen efter gennemsigtighed i forskningsprocessen.

Min skiftende positionering som ansat, forsker og ven, gav mig, som illustreret ovenfor, anledning til at reflektere over eventuelle implikationer af både at indtage og blive tilskrevet disse forskellige roller gennem forskningsforløbet. Jeg mener f.eks., at det er væsentligt, at nogle af kvinderne betragtede mig som 'allieret', 'troværdig' eller til og med som 'ven' allerede på det tidspunkt, hvor jeg startede med at udføre livshistorieinterviews. Tidligt i forskningsprocessen tænkte jeg på disse relationer som nogle, de valgte af forskellige grunde. Retrospektivt er det dog tydeligt, at de kvinder, som først og fremmest tiltrak sig min opmærksomhed, sympati og identifikation, havde bestemte træk og strategier til fælles, som jeg kunne genkende og respektere. Dette rejser et epistemologisk vigtigt og mere generelt spørgsmål omkring implikationerne af at gøre feltarbejde som ven eller allieret på et politiseret felt i eget samfund. Når jeg tænker på forskningsprojektet i lyset af min feltarbejdskrise og efterfølgende konstruktion af min egen livshistorie, fremstår det som sandsynligt, at min interesse for prostitution og for 'den prostituerede' som stigmatiseret figur havde sine rødder i min egen personlige erfaring med marginalisering og med oplevelse af begrænset agens. Jeg 'udvalgte' en marginaliseret gruppe uden offentlig stemme, og jeg så det som min opgave at hjælpe dem (og dermed mig selv?) til at få en. Dette kan forklare, hvorfor de kvinder, som benyttede det, jeg kalder for 'vilde taktikker', dem som jeg betragtede som mest selv-refleksive, og dem som oplevede, at de var misforstået og udsat for uretfærdighed, var dem, som interesserede mig mest, og som også blev mine nøgleinformanter og venner.
Det, jeg tolkede som deres kamp for værdighed og for at få stemme, fik mig til at genkende dem, respektere dem og holde af dem.

Spørgsmålet er så, hvordan mit mere eller mindre refleksive forsøg på at forstå og repræsentere 'andetgjorte' kvinder som reflekterende og kompetente påvirkede vidensproduktionen. I hvilken forstand var mit valg af de nøgleinformanter, som jeg anså som fornuftige og sammenhængende, samtidigt et forsøg på at konstruere dem, og indirekte mig selv, som forståelige og respektable aktører? 10

Min interesse og omsorg for dem medvirkede sandsynligvis til, at nogle ønskede at deltage $\mathrm{i}$ interviews og til at præsentere sig selv (Goffman 1963) i overensstemmelse med det, de forventede, at denne specifikke situation, og vores relation, krævede. De ville hjælpe mig ved at fortælle de typer af narrativer, som de troede, jeg ønskede. Andre har søgt at fremstå som kontrolleret og argumenterede på måder, som jeg kunne genkende som 'rationelle', 'smarte' og 'stolte'. Jeg tror, de fornemmede, at der fra min side var en tendens til at anerkende deres rationalitet og stolthed snarere end deres 'kaos'. Spørgsmålet er, hvad de epistemologiske implikationer af en sådan ikkebevidst udvælgelsesproces fra min side er. Jeg tenderede måske til at fokusere på, hvad jeg (mis)forstod som værdighedskampe og rationalitet, fordi det gav mening $\mathrm{i}$ lyset af min egen livshistorie og sociale position. En sådan 'normalisering' af informanterne (Vitus 2013: 86-88) skete f.eks., da jeg undlod at skrive om en række af de handlinger, jeg betragtede som mest degraderende for kvinderne med de 'vilde' taktikker, fordi jeg ikke ønskede at bidrage til den diskurs i Danmark, hvor 'den prostituerede' udelukkende blev betragtet som 'anderledes' og 'offer'.

Man kan i dette lys stille spørgsmål ved, om mit ønske om en symmetrisk relation med kvinderne med de 'vilde' taktikker i sidste ende medvirkede til, at det blev svært 
for mig at 'opdage' og repræsentere forskellighed (Young 1997: 342). Det er muligt, at der i interviews mellem 'venner' produceres repræsentationer af genkendelse og enshed, hvor der faktisk også er forskel, hvorved disse repræsentationer implicerer en subtil form for symbolsk vold, pakket ind i metodiske kapitler om anerkendelse, respekt og transparens.

I et ideologisk 'forurenet' felt som prostitution skal man være specielt opmærksom på denne type problemstillinger og på, hvorvidt og hvordan forskning intentionelt eller ikke-intentionelt bliver brugt som spydspids for bestemte moralske eller ideologiske positioner. Al forskning er engageret og dermed i en vis forstand 'biased'. Forskerens selvobjektiverende blik kan dog kun delvis befri forskeren fra de magtstrukturer, hun selv er positioneret i og en del af (Bourdieu 1995: 246; Skilbrei 2003). Bourdieus anbefaling af "epistemologisk påpasselighed"(2005: 142) bæres af et ønske om en gennemsigtig forskningsproces, hvor der er en altid tilstedeværende refleksion over egne reaktioner, tolkninger og eventuelle følelsesmæssige blokeringer. I konstruktionen af et mulighedsrum mellem informanters habitus og feltet er det nødvendigt også at inddrage de trak ved den habitus, man selv som forsker bringer ind i feltet (Bourdieu 2005). Dog er forskerens evne til at reflektere over egen bias begrænset:

Stillingen i kampen om klassifikationerne afhænger af stillingen i klassestrukturen, og sociale subjekter - indbefattet de intellektuelle, som slet ikke er de, der er bedst placeret for at forstå hvad som definerer grænserne for deres egen tænkning om den sociale verden, nemlig illusionen om fravær af grænser - har næppe nogensinde dårligere muligheder til at kunne overskride 'hjernens grænser' end netop i forestillingerne de selv har og giver andre om egen stilling, og det er jo den, der definerer disse grænser (Bourdieu 1995: 246).

Empirisk forankret refleksion er således nødvendig, ikke fordi det skaber mere objektiv viden, men fordi det muliggør en dybere forståelse for, hvilke forhold som påvirker forskningsprojektets kontekster, processer og resultater.

\section{Noter}

1. Artiklen bygger på et langvarigt feltarbejde på Stedet, et være- og omsorgssted for kvinder 'i misbrug og prostitution', fra 2001-2004. Jeg foretog i perioden livshistorieinterviews med 37 danske, kvindelige brugere (20-55 år). Interviews varede mellem to og 21 timer, fordelt på mellem en og syv sessioner, og alle blev optaget med diktafon. Derudover trækker jeg på mine erfaringer som ansat på Stedet både som frivillig (1999), social medarbejder og souschef (2004-2011). I tillæg bygger artiklen på et projekt, jeg udførte for Socialministeriet, Rådet for Socialt Udsatte, i 2009-2010, som fokuserede på forholdet mellem behandlere og klienter i stofmisbrugsbehandlingen. Jeg interviewede 30 kvindelige brugere (22-53 år). Interviews tog mellem en og tre timer (alle optaget), og foregik enten på misbrugscentret eller i informanternes eget hjem. Jeg interviewede også 30 misbrugsbehandlere på de samme behandlingscentre. Nærværende artikel er en omarbejdet version af artiklen "Contamination or engagement? Doing class in prostitution research" publiceret i Prostitution Research in Context. Methodology, Representation and Power redigeret af May-Len Skilbrei og Marlene Spanger.

2. Siden 1970erne har relationen mellem forsker og informant tiltagende blevet forstået som ' $k ø n$ net' og 'racet', mens 'klasse' ikke har haft så stor bevågenhed (Maher 1997; Hastrup 2010; Bourgois 2003; Skilbrei 2003; Bjønness 2012).

3 . 'Social position' er et analytisk begreb, brugt som Bourdieu gør det, til at understrege den sociale aktørs rolle i at udøve, gennem kropsliggørelsen af sociale strukturer, symbolsk orden. 'Rolle' bruges til at beskrive forskellige egenskaber eller opgaver i mere specifikke sociale kontekster, f.eks. 'ansat'.

4. Etnicitet og alder er også væsentlige aspekter, som ikke vil blive belyst her.

5. Bourdieu har, selv om store dele af hans forskning handler om betydningen af individers sociale oprindelse, været tilbageholdendende med at inddrage egen baggrund i sin forskning. Han henviser 
dog flere steder (f.eks. 1996: 185-195) hyppigt til egen baggrund netop for at begrebsliggøre hans position og valg som forsker. Blandt andet beskriver knytter han egen mistrivsel på College de France til egen opvækst i 'en afkrog i provinsen' (ibid:190).

6. Med emiske begreber menes de begreber, som bruges af informanterne selv, modsat etiske begreber, som ser kulturen 'udefra'.

7. Selv om jeg havde informeret brugerne om mit forskningsprojekt og min egen rolle som forsker, blev jeg umiddelbart tilskrevet rollen som 'ansat', og jeg indgik næsten fra start i vagtplanen.

8. Mine forældre var begge ufaglærte, min far arbejdede på et værksted og min mor som kassedame.

9. Bourdieu beskriver sin brug af egen erfaring som en slags "anti-selvbiografi" (1996:193), i det han netop bruger den for at afprøve grænserne for, hvad refleksivitet indenfor samfundsvidenskaberne vil sige.

10. Dette kan illustrere en mere general tendens til at forstå narrativ sammenhæng som kompetence og mangel på sammenhæng som inkompetence, hvilket kan få os til at privilegere interviews frem for observationer, fordi de er mere sammenhængende og dermed mere genkendelige (Skilbrei 2003; Loseke 2001).

\section{LITTERATUR}

- Ahmed, Akbar \& Shore, Chris (eds.) (1995): The Future of Anthropology. Its Relevance in the Contemporary World. Athlone, London.

- Becker, Howard S. (1963): Outsiders: Studies in the Sociology of Deviance. Free Press, New York.

- Becker, Howard S. (1967): Whose Side Are We On?, in: Social problems/14 (3).

- Bjønness, Jeanett (2008): Sociale tiltag som vidensproducent; Om sociale tiltag og erfaringsbaseret viden på prostitutionsfeltet i Danmark efter 1990, i: Charlotta Holmstrøm \& May-Len Skilbrei (red.): Prostitution i Norden. Tema Nord 2008: 604. Nordisk Ministerråd, København.

- Bjønness, Jeanett (2011): Jeg siger jo ikke jeg vil vere astronaut, vel? Rådet for Socialt Udsatte, København.

- Bjønness, Jeanett (2012): Between Emotional Politics and Biased Practices - Prostitution Policies, Social work, and Women Selling Sexual Services in Denmark, in: Sexuality Research and Social Policy/9 (3).
- Bourdieu, Pierre (1977): Outline of a Theory of Practice. Cambridge University Press, Cambridge. - Bourdieu, Pierre (1995 [1979]): Distinktionen. En sociologisk kritik af dømmekraften. Pax forlag, Oslo.

- Bourdieu, Pierre (1997[1990]): Af praktiske grunde. Hans Reitzels Forlag, København.

- Bourdieu, Pierre (1999) The Weight of the World. Social Suffering in Contemporary Society. Stanford University Press, Standford.

- Bourdieu, Pierre (2005): Viden om viden og refleksivitet. Hans Reitzels Forlag, København. - Bourdieu, Pierre \& Waquant, Loïc (1996 [1992]): Refleksiv Sociologi. Hans Reitzels Forlag, København.

- Bourgois, Philippe (2011): Homelessness, Addiction, and Politically Structured Suffering in the US war on drugs, in: Geoffrey Hunt; Maitena Milhet \& Henri Bergeron (eds.): Drugs and Culture. Knowledge, Consumption and Policy. Ashgate, Farnham.

- Bøge Pedersen, Merete (2000): Den reglementerede prostitution I København 1874-1906. Museum Tusculanums Forlag, København.

- Bømler, Tina U. (2008): Prostitutionssludren, i: Social Kritik/20 (116), pp 72-79.

- Ellis, Carolyn (2004): The Ethnographic I: A Methodological Novel About Autoethnography. Altamira Press, Walnut Creek.

- Faber, Stine Thidemann (2008): På jagt efter klasse. Ph.d.-thesis. Institut for Sociologi, Socialt arbejde og Organisation. Aalborg Universitet. - Goffman, Erving (1963): Stigma. Notes on the Management of Spoiled Identity. Penguin Books, London.

- Groes-Green, Christian (2002): Feltarbejdets forpligtelser, i: Tidsskriftet Antropologi/45.

- Gubrium, Jaber F. \& Järvinen, Margaretha (eds.) (2014): Turning Troubles into Problems: Clientization in Human Services. Routledge, London.

- Haraway, Donna (1988): Situated Knowledges:

The Science Question in Feminism and the Privilege of Partial Perspective, in: Feminist Studies/ 14(3).

- Hastrup, Kirsten (ed.) (2010): Ind $i$ verden. En grundbog $i$ antropologisk metode. Hans Reitzels Forlag, København.

- Helth, Hanne (2011): Fissehuller. Læserbrev Information. 22.2.2011.

- Jackson, Michael (2002): The Politics of Storytelling. Violence, Transgression and Intersubjectivity.

Museum Tusculanum Press, København. - Järvinen, Margaretha \& Mik-Meyer, Nanna (2003): At skabe en klient. Hans Reitzels Forlag, København. 
- Loseke, Donileen R. (2001): Lived Realities and Formula Stories of 'Battered Women', in: Jaber F. Gubrium \& James A. Holstein (eds.): Institutional Selves: Troubled Identities in a Postmodern World. Oxford University Press, New York. - Maher, Lisa (1997): Sexed Work. Gender, Race and Resistance in a Brooklyn Drug Market. Oxford University Press, New York.

- Margolin, Leslie (1997): Under the cover of kindness. The invention of social work. University Press of Virginia, Charlottesville.

- Mason, Jennifer (2002): Qualitative Interviewing: Asking, listening and interpreting, in: Tim May (ed.): Qualitative Research in action. Sage, London.

- Mazzei, Lisa A. (2009): An impossibly full voice, in: Alecia Y. Jackson \& Lisa A. Mazzei (eds.): Voice in Qualitative Inquiry. Routledge, London.

- Mattingly, Cheryl (1998): Healing dramas and Clinical Plots. The Narrative Structure of Experience. Cambridge University Press, London.

- NBSS (National Board of Social Services) (2014): Prostitutionens omfang $i$ Danmark. http://www.socialstyrelsen.dk/udsatte/prostitution/om-prostitution/prostitutionens-omfang-ogformer (Visited 8.8.2014)

. O'Connell Davidson, Julia \& Layder, Derek (1994): Methods, sex and madness. Routledge, London.

- O’Neill, Maggie (2001). Prostitution and feminism. Towards a Politics of Feeling. Polity Press, Cambridge.

- Rasmussen, Nell (2007): Prostitution i Danmark. Servicestyrelsen, København.

- Seljestad, Lars Ove (2005): Blind. Cappelen, Oslo.

- Skeggs, Beverley (1997): Formations of Class \& Gender. Sage, London.
· Skeggs, Beverley (2004): Class, self, culture.

Routledge, London.

- Skilbrei, May-Len (2003): Dette er jo bare en husmorjobb. Ufaglerte kvinner $i$ arbeidslivet. Dr.polit.avhandling. NOVA Rapport 17, Oslo.

- Skilbrei, May-Len \& Holmström, Charlotta (2013): Prostitution Policy in the Nordic Region: Ambigous Sympathies. Ashgate, Farnham.

- Stanley, Liz \& Wise, Sue (1993): Breaking Out Again: Feminist Ontology and Epistemology. Routledge, London.

- Spanger, Marlene (2011): Destabilising Sex Work o Intimacy: Gender Performances of Female Thai Migrants Selling Sex in Denmark. Ph.d.-afhandling. Roskilde Universitet.

- Sørensen, Anette Dina (2004): Pressen og prostitutionen: 1997-2002. København. VFC Socialt Udsatte. Arbejdspapir.

- Vitus, Kathrine (2014): Wild Girls and the Deproblematization of Troubled Lives, in: Jaber F. Gubrium \& Margaretha Järvinen (eds.): Turning Troubles into Problems. Routledge, UK.

- Wagner, Roy (1981): The Invention of Culture. University of Chicago Press, Chicago.

- Weitzer, Ronald (2005): Flawed Theory and Method in Studies of Prostitution, in: Violence Against Women/l (7).

- Weitzer, Ronald (2012): Legalizing Prostitution: From Illicit Vice to Lawful Business. New York University Press, New York.

. West, Candace \& Zimmerman, Don H. (1987):

Doing Gender, in: Gender \& Society/l(2).

- Widerberg, Karin (1995). Kunnskapens kjønn. Minner, refleksjoner og teori. Pax Forlag, Oslo. - Young, Iris Marion (1997): Intersecting Voices. Dilemmas of Gender, Political Philosophy, and Policy. Princeton University Press, Princeton. 